\title{
Vitamin D receptor gene polymorphisms in relation to the risk of colorectal cancer in the Polish population
}

\author{
Izabela Laczmanska • Lukasz Laczmanski • Marek Bebenek • Pawel Karpinski • \\ Halina Czemarmazowicz • David Ramsey • Andrzej Milewicz • Maria M. Sasiadek
}

Received: 10 June 2014 / Accepted: 26 August 2014 / Published online: 7 September 2014

(C) The Author(s) 2014. This article is published with open access at Springerlink.com

\begin{abstract}
The protective effect of vitamin D against several cancers including colorectal cancer is modulated by the vitamin D receptor (VDR) and its ligand, the active form of vitamin D. VDR response has been found to play a role in various genes encoding proteins involved in crucial cellular pathways. Single nucleotide polymorphisms (SNPs) of the VDR gene that modulate its activity are located in the promoter region, exons 2-9, and their vicinity and also in the $3^{\prime}$ UTR region. Some of them have been previously studied in relation to cancer susceptibility and prognosis. The aim of our study was to investigate four polymorphisms, BsmI, ApaI, TaqI, and FokI, of the VDR gene in Polish patients with sporadic colorectal cancer and to evaluate their association with susceptibility to cancer. We found a significant association between the $B s m \mathrm{I}$ genotype and cancer (individuals with the bb genotype are more susceptible to cancer compared to those with other genotypes, $p=0.025$, Fisher's exact test for $2 \times 2$ table). Also, the TT genotype at TaqI and the AA genotype at Apa $I$ are correlated with a higher risk of cancer ( $p=$ 0.00071 and $p=1.0 \times 10^{-5}$, respectively). We found relatively strong linkage disequilibrium between the TaqI and ApaI loci
\end{abstract}

I. Laczmanska • P. Karpinski • H. Czemarmazowicz •

M. M. Sasiadek

Genetics Department, Wroclaw Medical University, Wroclaw,

Poland

L. Laczmanski $(\varangle) \cdot$ A. Milewicz

Department of Endocrinology and Diabetology, Wroclaw Medical

University, Pasteura 4, Wroclaw, Poland

e-mail: lukasz.laczmanski@umed.wroc.pl

\section{Bebenek}

First Department of Surgical Oncology, Lower Silesian Oncology

Center, Wroclaw, Poland

\section{Ramsey}

Department of Computer Science and Management, Wroclaw

University of Technology, Wroclaw, Poland
( $\mathrm{T}$ with A and $\mathrm{t}$ with a, respectively). Both of these loci are associated with cancer. We do not observe any such association for the FokI polymorphism. In conclusion, a small modification in VDR expression may play a role in such a multipathway process as tumorigenesis.

Keywords Colorectal cancer · Vitamin D receptor · Gene polymorphisms

\section{Introduction}

Vitamin D is described to have a protective effect against several cancers including colorectal cancer, which is one of the most common cancers in the world [1]. This effect is modulated by the vitamin $\mathrm{D}$ receptor (VDR) and its ligand, the active form of vitamin $\mathrm{D}-1 \alpha, 25-(\mathrm{OH})_{2}-$ dihydroxyvitamin $\mathrm{D}\left(1,25(\mathrm{OH})_{2} \mathrm{D}_{3}\right.$, calcitriol). $1,25(\mathrm{OH})_{2} \mathrm{D}_{3}$ is produced locally in many tissues and is the most active natural metabolite of vitamin D [2]. VDR, an intracellular hormone receptor, is expressed in normal colon epithelial cells and other colon cells at various levels, and higher expression correlates with epithelial differentiation and better prognosis, while VDR downregulation is associated with poor prognosis and cancer progression [3]. VDR is a transcriptional regulatory factor that interacts with particular nucleotide sequences of target genes and is encoded by a gene of over $100 \mathrm{~kb}$ with two promoter regions, eight coding exons (from 2 to 9), and six untranslated exons (1a-1f) [4]. VDR response plays a role in various genes encoding proteins that act in, e.g., cellular growth, apoptosis, differentiation, or metastasis [2]. Over 60 single nucleotide polymorphisms (SNPs) of the VDR gene located in the promoter region, in exons 2-9, and their vicinity, as well as in the $3^{\prime} \mathrm{UTR}$ region, that modulate its activity have been described and some of them have been studied in relation to cancer susceptibility and prognosis $[1,2]$. A few of 
them are functional and affect expression of the VDR gene. These include the FokI (rs10735810) polymorphism located in the start codon, the major allele of which produces a protein shorter by three amino acids, and the BsmI (rs1544410), Apa I (rs7975232), and TaqI (rs731236) polymorphisms located in the $3^{\prime} \mathrm{UTR}$ region, all involved in regulating the stability of VDR mRNA [5]. The presence of the BAt haplotype (B allele of BsmI, A allele of ApaI, and t allele of TaqI) is associated with increased expression of VDR [5-7]. SNPs of the VDR gene can influence the level, activity, and properties of the gene transcription of proteins and therefore the biological functioning of vitamin $\mathrm{D}$ [8].

The relationship between polymorphisms of the VDR gene and sporadic colorectal cancer has been previously studied [4, 8]. Meta-analysis of a large number of studies revealed that the bb genotype at the BsmI polymorphism of the VDR gene is associated with an increased risk of colon cancer, particularly in the Asian population, although no association with other polymorphisms has been reported $[4,8]$.

The aim of our study was to investigate four polymorphisms, BsmI, ApaI, TaqI, and FokI, of the VDR gene in Polish patients with sporadic colorectal cancer and to evaluate their association with the risk of cancer.

\section{Materials and methods}

One hundred seventy-nine sporadic colorectal cancers (CRCs) obtained after surgery from the First Department of Surgical Oncology at the Lower Silesian Oncology Centre in Wroclaw were molecularly characterized, including analysis of the BRAF V600E (exon 15) and K-ras (codon 12 and codon 13) mutations, methylator phenotype (CIMP), and chromosomal instability [9]. The mean age of patients was 65.7 with a standard deviation of 11.2; the number of women was 73 (40.78\%) and the number of men was 106 (59.22\%). All of them were diagnosed with adenocarcinoma coli. Biological material was collected before chemo- and radiotherapy. All the patients were interviewed in regard to their family history of cancer, and those with hereditary cancer syndromes were excluded from the study group. One hundred eighty healthy individuals from the control group were matched according to sex and age.

The study design was accepted by the Ethical Committee of Wroclaw Medical University.

The analysis of the VDR gene polymorphisms, ApaI, BsmI, FokI, and TaqI, was determined using SNaPshot reaction according to the producer's protocol (SNaPshot Multiplex Kit, Applied Biosystems) [10] preceded by PCR with a 10x buffer containing $15 \mathrm{mM} \mathrm{MgCl}_{2}, 2 \mu \mathrm{l}$ (Qiagen); dNTP ( $2 \mathrm{mM}$ each, Fermentas), $2 \mu \mathrm{l}$; TaqI polymerase (5 U/ $\mu \mathrm{l}$, Qiagen), $0.3 \mu \mathrm{l}$; primers $(10 \mathrm{mM}), 1 \mu \mathrm{l}$; and $\mathrm{H}_{2} \mathrm{O}, 7.7 \mu \mathrm{l}$ to a final volume of
$18 \mu \mathrm{l}$. These primer sequences are described by Lins et al. [11].

The following PCR and SNaPshot conditions were previously described [12].

Products were separated using an ABI 310 Genetic Analyser with GeneScan Analysis version 3.1.2 software (Applied Biosystems), POP-4 Polymer (Applied Biosystems), and the LIZ 120 size standard (Applied Biosystems) for $15 \mathrm{~min}$. Analysis of the results was performed using GeneMarker version 1.85 software (SoftGenetics LLC).

\section{Statistical analysis}

The chi-squared goodness of fit test was used to investigate the existence of linkage disequilibrium between the rs10735810 (FokI), rs1544410 (BsmI), rs7975232 (Apa), and rs731236 (TaqI) VDR polymorphisms and whether the genotype frequencies were in agreement with the HardyWeinberg equilibrium. When analyzing linkage disequilibrium, an iterative gene counting procedure was used to estimate the haplotype frequencies [13]. Fisher's exact test was used to analyze the association between the genotypes are these loci and colorectal cancer. The CHAID procedure for hierarchical analysis of these associations was also applied [14].

\section{Results}

The patients were aged between 32 and 87 , with a mean age of 65.7 and a standard deviation of 112. It should be noted that there are significantly more males in the study group than females (binomial test, $p=0.017$ ), which may indicate that males are more susceptible to colorectal cancer.

The distribution of the genotypes at the ApaI and TaqI polymorphisms is consistent with the $\mathrm{H}-\mathrm{W}$ law in the control group (ApaI $p=0.1675, \operatorname{Taq} \mathrm{I} p=0.1344$ ), but not in the CRC group (ApaI $p=0.0085$, TaqI $p=0.0230$ ). The FokI polymorphism does not show a significant deviation from the Hardy-Weinberg equilibrium in either the control of CRC group ( $p=0.8534$ and $p=0.5616$, respectively). The distribution of BsmI genotypes shows a very strong deviation from the Hardy-Weinberg equilibrium, even in the control group $\left(p<10^{-5}\right.$, see Table 1). We do not observe any association between the FokI polymorphism and colorectal cancer, and there is no linkage disequilibrium with the other loci. There is relatively strong linkage disequilibrium between the TaqI and ApaI loci in both the study and control groups. The T allele at TaqI is associated with the A allele at ApaI. The t allele at TaqI is associated with the a 
Table 1 Hardy-Weinberg equilibrium
Numbers in brackets give \% value * Significant difference from Hardy-Weinberg equilibrium

\begin{tabular}{|c|c|c|c|c|c|}
\hline Polymorphism & Genotype & Observed & Expected & Chi-square & $p$ value \\
\hline \multicolumn{6}{|l|}{ Control group } \\
\hline \multirow[t]{3}{*}{ rs731236 (TaqI) } & $\mathrm{TT}$ & $57(31.9 \%)$ & $52.0(29.1 \%)$ & \multirow[t]{3}{*}{2.24} & \multirow[t]{3}{*}{0.1344} \\
\hline & $\mathrm{Tt}$ & $79(44.1 \%)$ & $89.0(49.7 \%)$ & & \\
\hline & $\mathrm{tt}$ & $43(24.1 \%)$ & $38.0(21.2 \%)$ & & \\
\hline \multirow[t]{3}{*}{ rs7975232 (ApaI) } & $\mathrm{AA}$ & $29(15.4 \%)$ & $33.6(17.9 \%)$ & \multirow[t]{3}{*}{1.9} & \multirow[t]{3}{*}{0.1675} \\
\hline & $\mathrm{Aa}$ & $101(53.7 \%)$ & $91.8(48.8 \%)$ & & \\
\hline & aa & $58(30.9 \%)$ & $62.6(33.3 \%)$ & & \\
\hline \multirow[t]{3}{*}{ rs1544410 (BsmI) } & $\mathrm{BB}$ & $86(45.7 \%)$ & $71.6(38.1 \%)$ & \multirow[t]{3}{*}{19.82} & \multirow[t]{3}{*}{$0.0000^{*}$} \\
\hline & $\mathrm{Bb}$ & $60(31.9 \%)$ & $88.9(47.3 \%)$ & & \\
\hline & $\mathrm{bb}$ & $42(22.3 \%)$ & $27.6(14.7 \%)$ & & \\
\hline \multirow[t]{3}{*}{ rs10735810 (FokI) } & FF & $62(33.0 \%)$ & $62.6(33.3 \%)$ & \multirow[t]{3}{*}{0.03} & \multirow[t]{3}{*}{0.8534} \\
\hline & $\mathrm{Ff}$ & $93(49.5 \%)$ & $91.8(48.8 \%)$ & & \\
\hline & $\mathrm{ff}$ & $33(17.6 \%)$ & $33.6(17.9 \%)$ & & \\
\hline \multicolumn{6}{|l|}{ Study group } \\
\hline \multirow[t]{3}{*}{ rs $731236($ TaqI) } & TT & $74(47.2 \%)$ & $67.6(43.1 \%)$ & \multirow[t]{3}{*}{5.17} & \multirow[t]{3}{*}{$0.0230^{*}$} \\
\hline & $\mathrm{Tt}$ & $58(36.9 \%)$ & $70.9(45.1 \%)$ & & \\
\hline & $\mathrm{tt}$ & $25(15.9 \%)$ & $18.6(11.8 \%)$ & & \\
\hline \multirow[t]{3}{*}{ rs7975232 (Apa $)$} & $\mathrm{AA}$ & $58(37.4 \%)$ & $50.0(32.2 \%)$ & \multirow[t]{3}{*}{6.92} & \multirow[t]{3}{*}{$0.0085^{*}$} \\
\hline & $\mathrm{Aa}$ & $60(38.7 \%)$ & $76.0(49.1 \%)$ & & \\
\hline & aa & $37(23.9 \%)$ & $29.0(18.7 \%)$ & & \\
\hline \multirow[t]{3}{*}{ rs1544410 (BsmI) } & $\mathrm{BB}$ & $38(41.3 \%)$ & $24.0(26.1 \%)$ & \multirow[t]{3}{*}{34.07} & \multirow[t]{3}{*}{$0.0000^{*}$} \\
\hline & $\mathrm{Bb}$ & $18(19.6 \%)$ & $46.0(50.0 \%)$ & & \\
\hline & $\mathrm{bb}$ & $36(39.1 \%)$ & $22.0(23.9 \%)$ & & \\
\hline \multirow[t]{3}{*}{ rs10735810 (FokI) } & $\mathrm{FF}$ & $47(28.7 \%)$ & $48.8(29.8 \%)$ & \multirow[t]{3}{*}{0.34} & \multirow[t]{3}{*}{0.5616} \\
\hline & $\mathrm{Ff}$ & $85(51.8 \%)$ & $81.3(49.6 \%)$ & & \\
\hline & $\mathrm{ff}$ & $32(19.5 \%)$ & $33.8(20.6 \%)$ & & \\
\hline
\end{tabular}

allele at ApaI. Both of these loci are associated with cancer. Those with the TT genotype at TaqI and the AA genotype at ApaI are more susceptible to cancer than those with other genotypes $\left(p=0.0071\right.$ and $p=10 \times 10^{-5}$, respectively, Fisher's exact test for $2 \times 2$ table). There is a significant association between the BsmI genotype and cancer. Those with the bb genotype are more susceptible to cancer, $p=$ 0.025 (see also Table 2).

\section{Discussion}

There is no doubt that the risk of sporadic colorectal cancer is associated with such environmental factors as dietary habits, lifestyle, and also genetic factors. It has also been revealed that vitamin D intake and the level of 25-hydroxyvitamin D in serum are inversely associated with colorectal cancer [4]. The role of VDR in various cellular pathways suggests it plays a
Table 2 Frequencies of genotypes of VDR polymorphisms in sporadic $\mathrm{CRC}$

$n / d$ not determined

${ }^{\text {a }}$ OR of TT genotype with respect to other genotypes

${ }^{\mathrm{b}}$ OR of AA genotype with respect to other genotypes

${ }^{\mathrm{c}} \mathrm{OR}$ of bb genotype with respect to other genotypes

${ }^{\mathrm{d}}$ Using Fisher's exact test for association for the $3 \times 2$ table

\begin{tabular}{|c|c|c|c|c|c|c|c|}
\hline Polymorphism & Genotype & $\mathrm{CRC}$ & Control & Chi-square & $p$ value $^{\mathrm{d}}$ & OR & $95 \% \mathrm{CI}$ \\
\hline \multirow[t]{3}{*}{ rs731236 (TaqI) } & TT & $74(47 \%)$ & $57(33 \%)$ & \multirow[t]{3}{*}{7.655} & \multirow[t]{3}{*}{0.0220} & \multirow[t]{3}{*}{$1.84^{\mathrm{a}}$} & \multirow[t]{3}{*}{$1.15-2.95$} \\
\hline & $\mathrm{Tt}$ & $58(37 \%)$ & $78(44 \%)$ & & & & \\
\hline & $\mathrm{tt}$ & $25(16 \%)$ & $40(23 \%)$ & & & & \\
\hline \multirow[t]{3}{*}{ rs7975232 (Apal) } & AA & $58(37 \%)$ & $29(16 \%)$ & \multirow[t]{3}{*}{20.479} & \multirow[t]{3}{*}{0.0000} & \multirow[t]{3}{*}{$3.14^{\mathrm{b}}$} & \multirow[t]{3}{*}{$1.84-5.47$} \\
\hline & $\mathrm{Aa}$ & $60(39 \%)$ & $100(55 \%)$ & & & & \\
\hline & aa & $37(24 \%)$ & $53(29 \%)$ & & & & \\
\hline \multirow[t]{3}{*}{ rs1544410 (BsmI) } & $\mathrm{BB}$ & $38(41 \%)$ & $42(46 \%)$ & \multirow[t]{3}{*}{6.316} & \multirow[t]{3}{*}{0.0411} & \multirow[t]{3}{*}{$2.13^{\mathrm{c}}$} & \multirow[t]{3}{*}{$1.08-4.31$} \\
\hline & $\mathrm{Bb}$ & $18(20 \%)$ & $28(31 \%)$ & & & & \\
\hline & $\mathrm{bb}$ & $36(39 \%)$ & $21(23 \%)$ & & & & \\
\hline \multirow[t]{3}{*}{ rs10735810 (FokI) } & $\mathrm{FF}$ & $47(29 \%)$ & $60(33 \%)$ & \multirow[t]{3}{*}{0.866} & \multirow[t]{3}{*}{0.6553} & \multirow[t]{3}{*}{$\mathrm{n} / \mathrm{d}$} & \multirow[t]{3}{*}{$\mathrm{n} / \mathrm{d}$} \\
\hline & $\mathrm{Ff}$ & $85(52 \%)$ & $91(50 \%)$ & & & & \\
\hline & $\mathrm{ff}$ & $32(19 \%)$ & $31(17 \%)$ & & & & \\
\hline
\end{tabular}


crucial role in the etiology and development of cancer [15]. Many studies on VDR gene polymorphisms and sporadic CRC have shown a reduced risk of CRC for patients with the B allele of BsmI, f allele of FokI and A allele of ApaI, and $\mathrm{t}$ allele of TaqI, which are associated with higher activity of the vitamin D receptor, but the influence of SNPs on cancerogenesis may be modified by many elements including the environment, lifestyle, and many other genetic factors [2, $8,16]$. In our study, we found that the following genotypes are associated with a higher risk of colorectal cancer: the bb (CC) genotype at the BsmI locus, the TT (AA) genotype at TaqI, and the AA (GG) genotype at ApaI. There is no statistical evidence for any association with FokI (5'-end polymorphism). We observed relatively strong linkage disequilibrium between the TaqI and ApaI loci in both the study and control groups. The $\mathrm{T}$ allele at TaqI is associated with the A allele at ApaI. The t allele at TaqI is associated with the a allele at ApaI. When the association of the ApaI genotype to cancer is taken into account, there is no significant association between the TaqI genotype and cancer. However, when the association of the TaqI genotype to cancer is taken into account, the association between the ApaI genotype remains significant. This suggests that the ApaI genotype is more important in modulating an individual's susceptibility to cancer, and the association between the TaqI genotype and cancer may result from the linkage disequilibrium between TaqI and ApaI.

We also found a significant association between the BsmI genotype and cancer. Those with the bb genotype are more susceptible to cancer. However, the association between the BsmI locus and the TaqI locus is very odd. In the control group, there is linkage disequilibrium of medium strength between TaqI and BsmI. In the study group, the degree of linkage disequilibrium is large. The data indicate that among those whose Bsm I genotype is bb (high risk), those who also have genotype TT at Taq I are clearly more susceptible to cancer. However, among those whose BsmI genotype is not bb (lower risk), those who have genotype TT at TaqI are clearly less susceptible to cancer.

Results from various meta-analyses have clearly shown the statistically significant association of the B allele of BsmI with reduced sporadic $C R C$ risk using both a dominant model $(\mathrm{BB}+\mathrm{Bb}$ versus $\mathrm{bb})$ and recessive model $(\mathrm{BB}$ versus $\mathrm{Bb}+$ bb) $[2,8]$. Our results are in agreement with other studies considering Bsm I, which suggest that the B allele of the Bsm I polymorphism has a protective effect against cancerogenesis in a variety of ethnical populations [8]. The BsmI polymorphism does not modify the amino acid sequence of proteins, mRNA, or protein levels. However, it exhibits strong linkage disequilibrium with other VDR SNPs, including ApaI and TaqI. This suggests that the BsmI, ApaI, and TaqI polymorphisms have a significant influence on VDR expression or mRNA processing [17].
Results obtained from many studies and observed in metaanalyses are the most reliable and have the highest statistical value. Numerous studies on different gene polymorphisms have shown that SNPs should be examined and interpreted in functional groups (e.g., groups of polymorphisms that reduce or enhance an enzyme's activity) [2,8]. Although the conclusions obtained are sometimes contradictory because of differing features of various populations, ethnic differences, and even differences between groups of patients, the accumulation of data from many published results is statistically more valid and can detect genetic associations with higher accuracy, while reducing the probability of false-negative results $[4,8$, $18]$.

\section{Conclusion}

Even a small modification in VDR activity or ligand affinity may play a crucial role in such a multipathway process as tumorigenesis due to the significant engagement of VDR in biological processes in cells and its role in homeostasis.

Acknowledgments This paper has been supported by the State Committee for Scientific Research, Polish Ministry for Scientific Research and Information Technology (grant no. N N401 601438).

Open Access This article is distributed under the terms of the Creative Commons Attribution License which permits any use, distribution, and reproduction in any medium, provided the original author(s) and the source are credited.

\section{References}

1. Perna L, Hoffmeister M, Schöttker B, Arndt V, Haug U, Holleczek B, et al. Vitamin D receptor polymorphism and colorectal cancerspecific and all-cause mortality. Cancer Epidemiol. 2013;37:905-7.

2. Köstner K, Denzer N, Müller CS, Klein R, Tilgen W, Reichrath J. The relevance of vitamin $\mathrm{D}$ receptor (VDR) gene polymorphisms for cancer: a review of the literature. Anticancer Res. 2009;29:3511-36.

3. Di Rosa M, Malaguarnera M, Zanghì A, Passaniti A, Malaguarnera L. Vitamin D3 insufficiency and colorectal cancer. Crit Rev Oncol Hematol. 2013;88:594-612.

4. Touvier M, Chan DS, Lau R, Aune D, Vieira R, Greenwood DC, et al. Meta-analyses of vitamin D intake, 25-hydroxyvitamin D status, vitamin $\mathrm{D}$ receptor polymorphisms, and colorectal cancer risk. Cancer Epidemiol Biomarkers Prev. 2011;20:1003-16.

5. Uitterlinden A, Fang Y, Van Meurs J, Pols H, Van Leeuwen J. Genetics and biology of vitamin D receptor polymorphisms. Gene. 2004;338:143-56.

6. Morrison NA, Qi JC, Tokita A, Kelly PJ, Crofts L, Nguyen TV, et al. Prediction of bone density from vitamin D receptor alleles. Nature. 1994;367:284-7.

7. Howard G, Nguyen T, Morrison N, Watanabe T, Sambrook P, Eisman $\mathrm{J}$, et al. Genetic influences on bone density: physiological correlates of vitamin D receptor gene alleles in premenopausal women. J Clin Endocrinol Metab. 1995;80:2800-5. 
8. Bai YH, Lu H, Hong D, Lin CC, Yu Z, Chen BC. Vitamin D receptor gene polymorphisms and colorectal cancer risk: a systematic metaanalysis. World J Gastroenterol. 2012;18:1672-9.

9. Karpinski P, Szmida E, Misiak B, Ramsey D, Leszczynski P, Bebenek M, et al. Assessment of three epigenotypes in colorectal cancer by combined bisulfite restriction analysis. Mol Carcinog. 2012;51:1003-8.

10. Laczmanska I, Pesz K, Laczmanski L. Application of selected methods based on the polymerase chain reaction in medical molecular diagnostics. Adv Clin Exp Med. 2009;18:85-92.

11. Lins TCL, Nogueira LR, Lima RM, Gentil P, Oliveira RJ, Pereira RW. A multiplex single-base extension protocol for genotyping Cdx2, FokI, BsmI, ApaI, and TaqI polymorphisms of the vitamin D receptor gene. Genet Mol Res. 2007;6:316-24.

12. Laczmanski L, Milewicz A, Puzianowska-Kuznicka M, Lwow F, Kolackov K, Mieszczanowicz U, et al. Interrelation between genotypes of the vitamin D receptor gene and serum sex hormone concentrations in the Polish elderly population: the PolSenior study. Exp Gerontol. 2014. doi:10.1016/j.exger.2014.06.007.2014.
13. Yasuda N, Tsuji K. A counting method of maximum likelihood for estimating haplotype frequency in the HL-A system. Jinrui Idengaku Zasshi. 1975;20:1-15.

14. Kass GV. An exploratory technique for investigating large quantities of categorical data. Appl Stat. 1980;29:119-27.

15. Slattery ML, Herrick J, Wolff RK, Caan BJ, Potter JD, Sweeney C. CDX2 VDR polymorphism and colorectal cancer. Cancer Epidemiol Biomarkers Prev. 2007;16:2752-5.

16. Slattery ML. Vitamin D, receptor gene (VDR) associations with cancer. Nutr Rev. 2007;65:S102-4.

17. Parisi E, Reñé JM, Cardús A, Valcheva P, Piñol-Felis C, Valdivielso $\mathrm{JM}$, et al. Vitamin D receptor levels in colorectal cancer. Possible role of BsmI polymorphism. J Steroid Biochem Mol Biol. 2008;111:8790.

18. Fedirko V, Riboli E, Tjønneland A, Ferrari P, Olsen A, Bueno-deMesquita HB, et al. Prediagnostic 25-hydroxyvitamin D, VDR and CASR polymorphisms, and survival in patients with colorectal cancer in western European populations. Cancer Epidemiol Biomarkers Prev. 2012;21:582-93. 